\title{
2. NATURAL AND EXPERIMENTAL PHASE RELATIONS OF LAVAS FROM SEROCKI VOLCANO ${ }^{1}$
}

\author{
Timothy L. Grove,$^{2}$ Rosamond J. Kinzler, ${ }^{2}$ and Wilfred B. Bryan ${ }^{3}$
}

\begin{abstract}
Phase equilibrium experiments on Serocki lava ALV-1690-20 have been carried out at 1 atm and 8 kbar. The results provide a framework for quantifying the effects of fractional crystallization on the abundant parental group MORB near the Kane Fracture Zone (KFZ), Mid-Atlantic Ridge. The least-evolved parental group MORBs, as exemplified by Serocki lava ALV-1690-20, are not in equilibrium with a mantle peridotite residue in the plagioclase stability field. Multiply saturated liquids from $8 \mathrm{kbar}$ experiments have pigeonite as their low-Ca pyroxene, and have low $\mathrm{Mg}$, high $\mathrm{Na}_{2} \mathrm{O}$ and high $\mathrm{TiO}_{2}$ compared to the parental group lavas. The variation in composition between glass and whole rock from Serocki volcano can be accounted for by plagioclase accumulation. Elevated pressure fractional crystallization of olivine, plagioclase, and augite at 5-6 kbar can account for compositional variation in spatially related lavas from the vicinity of Serocki volcano. Plagioclase phenocrysts or xenocrysts, which are abundant in Serocki lavas, did not crystallize from a liquid of Serocki lava composition at any pressure under anhydrous conditions. These exotic An-rich plagioclase $\left(\mathrm{An}_{84}\right)$ may have crystallized at elevated pressure from a precursor magma with higher $\mathrm{MgO}$ and $\mathrm{CaO}$ and lower $\mathrm{Na}_{2} \mathrm{O}$ contents, or may record a mixing event with a distinctively low- $\mathrm{Na}_{2} \mathrm{O}$ magma type.
\end{abstract}

\section{INTRODUCTION}

This paper presents elevated pressure phase relations on a lava from Serocki volcano. The experiments quantify the liquid line of descent, the major element mineral/melt distribution coefficients, the phase appearance sequence, and phase proportions expected for crystallization at pressures of $1 \mathrm{~atm}$ and $8 \mathrm{kbar}$. The results are used to test models of fractional crystallization at elevated pressure, and provide information necessary for evaluating more complex open system magmatic processes proposed for generating compositional variability in Kane Fracture Zone lavas.

The discussion will be limited to lavas collected from the vicinity of Serocki volcano, a small volcanic feature on "zero-age" crust near $22^{\circ} 55^{\prime} \mathrm{N}$ on the Mid-Atlantic ridge, which was sampled by drilling at Site 648 . The starting material for the experimental study was sample ALV-1690-20, collected by submersible Alvin from the pillow lavas near the summit of Serocki volcano. This sample was chosen because it was typical of the mafic end of the compositional range spanned by lavas from Site 648. ALV-1690-20 was also fresh, glassy, and available in large quantities, so it was used in preference to samples obtained by drilling at Site 648 . The compositional spectrum of lavas discussed in this paper is comprised of samples recovered by drilling at Site 648 and by submersible operation.

\section{EXPERIMENTAL METHODS}

\section{Experiments}

Sample ALV-1690-20 consists of fresh glassy to aphyric pillow buds containing $2 \%-4 \%$ phenocrysts $(1-3 \mathrm{~mm})$ of plagioclase. The freshest parts of the pillows were reduced to powder by grinding in a SPEX shatterbox for $3 \mathrm{~min}$ and then used as starting material. Table 1 provides chemical analyses of the starting composition used in this study. Melting experiments were carried out at $1 \mathrm{~atm}$ and $8 \mathrm{kbar}$ and

\footnotetext{
${ }^{1}$ Detrick, R., Honnorez, J., Bryan, W. B., Juteau, T., et al., 1990. Proc. ODP, Sci. Results, 106/109: College Station, TX (Ocean Drilling Program).

${ }^{2}$ Department of Earth, Atmospheric and Planetary Sciences, 54-1220, Massachusetts Institute of Technology, Cambridge, MA 02139.

${ }^{3}$ Woods Hole Oceanographic Institute, Woods Hole, MA 02543.
}

experimental conditions and phase appearance temperatures are reported in Table 2 and shown in Figure 1.

The 1-atm experiments used techniques similar to those described in Tormey et al. (1987). Pellets of ALV-1690-20 powder $(0.08-0.10 \mathrm{~g})$ were prepared using elvanol as a binder, and sintered to 0.008 -in. FePt alloy loops fabricated to minimize $\mathrm{Fe}$ exchange between the loop and silicate sample (Grove, 1981). Experiments at $1 \mathrm{~atm}$ were carried out in Deltech DT31VT quenching furnaces in a $\mathrm{CO}_{2}-\mathrm{H}_{2}$ gas atmosphere maintained at the quartz-fayalite-magnetite buffer, using gas flow rates of $0.1 \mathrm{~mL} / \mathrm{s}$. Oxygen fugacity was monitored using $\mathrm{ZrO}_{2}$ $\mathrm{CaO}$ electrolyte cells calibrated at the $\mathrm{Fe}-\mathrm{FeO}, \mathrm{Cu}-\mathrm{Cu}_{2} \mathrm{O}$, and $\mathrm{Ni}-\mathrm{NiO}$ buffers. Temperature was monitored using Pt-10Rh thermocouples calibrated against the melting points of $\mathrm{NaCl}, \mathrm{Au}$, and Pd on the IPTS 1968 temperature scale (Biggar, 1972). The exchange of Fe between loop and silicate charge, and the loss of $\mathrm{Na}$ from the silicate charge by volatilization in these 1-atm wire loop experiments have been essentially eliminated by using PtFe alloys, extremely low gas flow rates, and "large" sample sizes (Tormey et al., 1987).

High pressure experiments were carried out at 8 kbar using a $1 / 2$-in. solid-medium piston cylinder apparatus (Boyd and England, 1960). Temperature was controlled and monitored using Pt-10Rh thermocouples. Experiments were performed using the piston-in method (Johannes et al., 1971). A salt outer cell and pyrex inner cell served as the pressure medium and the reported pressure assumes no friction correction. We initially used FePt alloy capsules in the 8-kbar experiments. Although these capsules were successful in minimizing iron loss from the silicate charge, they were also very brittle and prone to leakage and failure. We found the results of graphite capsule experiments to be comparable to those of experiments which used FePt alloy capsules, and report both in Tables 2 and 3.

\section{Analytical Methods}

Experimentally produced run products were analyzed with the MIT 4-spectrometer JEOL 733 Superprobe and reduced using Bence and Albee (1968) matrix corrections with modifications of Albee and Ray (1970). The compositions of minerals and glasses are summarized in Table 3. The compositions of phases in each experiment (Table 3) were used to compute phase proportions by materials balance (Bryan et al., 1969) (reported in Table 2).

\section{EXPERIMENTAL RESULTS AND IMPLICATIONS}

\section{Liquid line of descent at 1 atm and 8 kbar}

The results of melting experiments on ALV-1690-20 at 1 atm and $8 \mathrm{kbar}$ are shown in Figure 1. At $1 \mathrm{~atm}$, ALV-1690-20 
Table 1. Analyses of ALV-1690-20 starting material.

\begin{tabular}{|c|c|c|c|c|}
\hline & A & B & C & D \\
\hline $\mathrm{SiO}_{2}$ & 50.15 & $49.9(3)^{\mathrm{a}}$ & 49.93 & 50.0 \\
\hline $\mathrm{Al}_{2} \mathrm{O}_{3}$ & 16.02 & 15.5 (1) & 15.73 & 15.7 \\
\hline $\mathrm{TiO}_{2}{ }^{3}$ & 1.72 & $1.71(3)$ & 1.73 & 1.66 \\
\hline $\mathrm{FeO}$ & 9.86 & $9.92(8)$ & 10.42 & 10.2 \\
\hline $\mathrm{MgO}$ & 7.64 & $7.68(9)$ & 7.54 & 7.78 \\
\hline $\mathrm{CaO}$ & 11.20 & 10.8 (2) & 11.01 & 11.0 \\
\hline $\mathrm{Na}_{2} \mathrm{O}$ & 2.91 & $3.13(6)$ & 2.92 & 3.07 \\
\hline $\mathrm{K}_{2} \mathrm{O}$ & 0.10 & 0.14 (1) & 0.15 & 0.13 \\
\hline $\mathrm{P}_{2} \mathrm{O}_{5}$ & 0.18 & $0.18(7)$ & 0.21 & 0.16 \\
\hline Sum & 99.78 & 99.05 & 99.64 & \\
\hline
\end{tabular}

A Whole rock XRF, WHOI (Woods Hole Oceanographic Institution)

B Natural glass, MIT electron microprobe, average of 106 analyses.

C Natural glass, Smithsonian electron microprobe.

D Fused whole rock, from Table 2

${ }^{\text {a }}$ Units in parentheses represent one standard deviation of replicate analyses in terms of least units cited. Thus, 49.9(3) should be read as $49.9 \pm 0.3$.

is multiply saturated on the liquidus with plagioclase (plag) + olivine (oliv) followed by oliv + plag + augite (aug). The lowest temperature experiment is not saturated with a low-Ca pyroxene, but by analogy with the 1-atm studies of Tormey et al. (1987) and Grove and Bryan (1983) on related KFZ lavas, pigeonite would be expected as a near-solidus phase. At 8 kbar, aug + plag are liquidus phases, followed by aug + plag + low-Ca pyroxene (pigeonite). The liquid then saturates with oliv at a peritectic reaction boundary. Pigeonite + liquid react to form oliv + aug, and after pigeonite is consumed, the liquid moves down an aug + plag + oliv cotectic to the solidus. At $8 \mathrm{kbar}, \mathrm{ALV}-1690-20$ is multiply saturated within $45^{\circ} \mathrm{C}$ of its liquidus and is $70 \%$ crystalline within $65^{\circ} \mathrm{C}$ of its liquidus.

The multiple saturation boundaries for ALV-1690-20 are shown in Figure 2 for $1 \mathrm{~atm}$ and $8 \mathrm{kbar}$ in the Oliv-Cpx-Qtz pseudoternary recalculated using oxygen units and the mineral component scheme of Tormey et al. (1987). Also shown are the 1-atm oliv + aug + plag and oliv + plag + aug + pigeonite saturated liquids from Tormey et al. (1987). During 1-atm fractional crystallization, a liquid with the bulk composition of ALV-1690-20 crystallizes oliv + plag, and moves away from the oliv apex to the oliv + aug + plag multiple saturation boundary. Further crystallization involves oliv, aug, and plag, with liquids evolving by fractionation to pigeonite saturation and quartz-normative residua. Fractional crystallization at $8 \mathrm{kbar}$ of the ALV-1690-20 composition involves the precipitation of aug + plag, which moves the liquid to an aug + pigeonite + plag boundary. Pigeonite joins the fractionating assemblage and further crystallization causes the liquid to evolve to a peritectic saturation boundary, where oliv appears as a crystallizing phase. Pigeonite disappears and the liquid moves through this 8-kbar peritectic boundary. Continued crystallization drives residual liquids along an oliv + plag + aug boundary to nepheline-normative residual liquid compositions.

\section{Multiple saturation at 8 kbar}

The position of the peritectic saturation boundary determined for ALV-1690-20 at 8 kbar is shown in Figure 3 with other 8- and 10-kbar multiple saturation "points" and boundaries inferred experimentally for MORB. Two of the best characterized high pressure experimental studies of primitive MORB, 527-1-1 (Bender et al., 1978) and ARP-74-10-16 (Fujii and Bougault, 1983) are presented for comparison. Neither study reports liquid compositions saturated with a low-Ca pyroxene, oliv, aug, and plag, but the position of a multiple saturation boundary can be inferred. Bender et al. (1978) report an oliv + plag + aug saturated liquid that is near multiple saturation (triangle in Fig. 3 ) and the bulk composition of the Fujii and Bougault (1983) study, ARP-74-10-16, is near multiple saturation (large solid circle, Fig. 3). Also plotted are the oliv + orthopyroxene (opx) saturated liquids, and the oliv + aug + plag saturated liquid which Stolper (1980) used to limit the position of melt generation from a mantle assemblage at $10 \mathrm{kbar}$.

All of these low-Ca pyroxene saturated liquid compositions plot in about the same part of mineral component space as our ALV-1690-20 multiply saturated liquid composition. The ALV-1690-20 multiply saturated liquid is not, however, one that we would characterize as a primary magma. It has a lower $\mathrm{Mg} \#$, and higher $\mathrm{TiO}_{2}, \mathrm{Na}_{2} \mathrm{O}$, and $\mathrm{K}_{2} \mathrm{O}$ abundances $(\mathrm{H} 10$ glass, Table 3 ) than any of the KFZ parental group MORB, and would not be a likely candidate as a partial melt separated from a mantle peridotite residue. Also, the liquid is saturated with pigeonite as its low-Ca pyroxene, rather than opx. Therefore, although multiply saturated liquids from experiments on ALV-1690-20 at 8 kbar resemble other experimentally inferred, potentially primary liquids at $8-10$ kbar in projection component space, they are actually significantly different (more evolved) in major element composition. Due to the nature of the projection scheme, a close correspondence in projected position results between the evolved multiple saturation equilibrium for ALV-1690-20 and similar low-Ca pyroxene saturated equilibria in more primitive MORBs. An important observation from this comparison is that while liquid compositions may plot similarly to experimentally determined melts of a mantle assemblage, and even be multiply saturated with a low-Ca pyroxene, their multiple saturation equilibria need to be fully and carefully characterized before being considered as primary. Phase compositions of solids and liquids are necessary to constrain the nature of multiple saturation boundaries and to evaluate the potential primary nature of natural compositions.

Further, our experiments enable us to constrain the low-Ca pyroxene saturation as a function of increasing pressure. At 1 atm, multiple saturation occurs at a reaction boundary where oliv + liquid $=$ pigeonite + aug + plag. As pressure increases, multiple saturation shifts to lower normative silica values in mineral component space. Based on linear extrapolation of the pressure effect on the projected positions of both the multiply saturated liquids and the coexisting augites (see discussion below) between $1 \mathrm{~atm}$ and $8 \mathrm{kbar}$, we predict a shift in the multiple saturation relationship from the 1-atm reaction described above, to a reaction relationship again at pressures $>6 \mathrm{kbar}$. The elevated pressure reaction boundary, however, differs from the 1-atm reaction boundary in that it involves the peritectic reaction: low-Ca pyroxene + liquid $=$ oliv + plag + aug. Figure 4 shows the peritectic nature of the 8 -kbar saturation in ALV-1690-20. The existence of this saturation as a peritectic has been suggested by Green and Ringwood (1967) and discussed by Stolper (1980), Green et al. (1979), and Basaltic Volcanism Study Project (1981, p. 510-512).

\section{Pressure effects on augite composition}

The change in position of the 5-phase (oliv + pig + aug + plag + liquid) saturation boundary provides an important limit on the pressure range over which fractionation of the assemblage oliv + aug + plag can produce "quartz" enrichment. The key constraint on the path followed by liquids evolving by fractional crystallization with changing pressure is the pres- 
Table 2. Run conditions and phase assemblages. See Table 3 for run compositions.

\begin{tabular}{|c|c|c|c|c|c|c|}
\hline$\underset{\#}{\text { Run }}$ & $\begin{array}{l}\mathrm{T} \\
{ }^{\circ} \mathrm{C}\end{array}$ & $\begin{array}{l}\log \\
f_{\mathrm{O} 2}\end{array}$ & $\begin{array}{l}\text { Duration } \\
\text { (hr) }\end{array}$ & Run products $^{\mathrm{a}}$ & $\begin{array}{l}\text { Phase } \\
\text { proportions } \\
\text { (wt.\%) }\end{array}$ & $\begin{array}{l}\text { Capsule } \\
\text { material }\end{array}$ \\
\hline \multicolumn{7}{|c|}{$1 \mathrm{~atm}$} \\
\hline 80 & 1214 & -8.25 & 5.1 & $\mathrm{gl}$ & 100 & \\
\hline 50 & 1210 & -8.25 & 9.4 & $\mathrm{gl}$ & 100 & \\
\hline 40 & 1205 & -8.41 & 5.7 & $\mathrm{gl}, \mathrm{pl}, \mathrm{ol}$ & $99: 1: \operatorname{tr}$ & \\
\hline 30 & 1201 & -8.37 & 22.7 & $\mathrm{gl}, \mathrm{pl}, \mathrm{ol}$ & $98.4: 1.4: 0.2$ & \\
\hline 20 & 1196 & -8.57 & 15.4 & $\mathrm{gl}, \mathrm{pl}, \mathrm{ol}$ & $98.4: 1.4: 0.2$ & \\
\hline 100 & 1174 & -8.81 & 49.6 & $\mathrm{gl}, \mathrm{pl}, \mathrm{ol}$ & $84: 12: 4$ & \\
\hline 110 & 1165 & -8.83 & 48.4 & $\mathrm{gl}, \mathrm{pl}, \mathrm{ol}$ & $79: 15: 6$ & \\
\hline 120 & 1152 & -9.02 & 70.2 & $\mathrm{gl}, \mathrm{pl}, \mathrm{ol}$,aug & $71: 21: 7: 1$ & \\
\hline 130 & 1137 & -9.23 & 70.8 & $\mathrm{gl}, \mathrm{pl}, \mathrm{ol}$,aug & $54: 29: 9: 8$ & \\
\hline 140 & 1123 & -9.42 & 96.3 & $\mathrm{gl}, \mathrm{pl}, \mathrm{ol}, \mathrm{aug}$ & $44: 35: 10: 11$ & \\
\hline 150 & 1108 & -9.70 & 147.5 & $\mathrm{gl}, \mathrm{pl}, \mathrm{ol}$,aug & $31: 41: 11: 16$ & \\
\hline \multicolumn{7}{|c|}{8 kbar } \\
\hline H36 & 1251 & & 5.9 & $\mathrm{gl}$ & & Graphite \\
\hline H6 & 1239 & & 2.5 & gl,aug,pl & & $\mathrm{FePt}$ \\
\hline H8 & 1233 & & 3.5 & gl,aug,pl & $86: 8: 6$ & $\mathrm{FePt}$ \\
\hline H7 & 1209 & & 9.0 & gl,pig,aug,pl & $57: 7: 14: 22$ & $\mathrm{FePt}$ \\
\hline H10 & 1199 & & 14.5 & gl,ol,pig,aug,pl & & $\mathrm{FePt}$ \\
\hline $\mathrm{H} 47$ & 1189 & & 14.8 & $\mathrm{gl}, \mathrm{ol}$, aug,pl & $29: 2: 31: 37$ & Graphite \\
\hline $\mathrm{H} 27$ & 1183 & & 14.8 & ol,aug,pl,sp & & Graphite \\
\hline
\end{tabular}

a Abbreviations: $\mathrm{gl}=$ glass; $\mathrm{pl}=$ plagioclase $; \mathrm{ol}=$ olivine; aug $=$ augite; $\mathrm{pig}=$ pigeonite; $\mathrm{sp}=$ spinel.

b Phase proportions calculated using unweighted materials balance.

sure dependency of the augite composition. In the case of the KFZ parental MORB lavas (e.g., ALV-1690-20), the pressure effect on the projected positions of the augites and the multiply saturated liquids is such that fractional crystallization of oliv + aug + plag at pressures $<5-6$ kbar produces quartz-enriched residual liquids. At pressures $>5-6 \mathrm{kbar}$ fractionation of these phases produces nepheline-normative residual liquids.

The effect of varying pressure, temperature, and melt composition on augite chemistry can be inferred from experiments in CMAS, but as Stolper (1980) and Biggar (1984) point out, the experimental results on natural MORB compositions give inconsistent results. Augite composition influences whether or not the low-Ca pyroxene reaction boundary is peritectic. As discussed above, the augite compositions in our experiments on ALV-1690-20 confirm the suggestion of Stolper (1980) and Green and Ringwood (1967) that the low-Ca pyroxene saturation at $8 \mathrm{kbar}$ and above is a peritectic equilibrium (Figs. 2 and 4). If the basalt composition is more FeO-enriched than ALV-1690-20, and low-Ca pyroxene saturation therefore occurs at a lower temperature, then the multiple saturation could change to a eutectic relation, in a similar pressure range, because of the temperature dependence of augite composition. The low-Ca pyroxene multiple saturation of Baker and Eggler (1987) is a eutectic. This point, determined on an iron-rich Aleutian basalt, occurs at $8 \mathrm{kbar}$ at $<1150^{\circ} \mathrm{C}$. The augite in these lower temperature experiments has a higher $\mathrm{Ca}$ content $\left(\mathrm{Wo}_{33} \mathrm{En}_{40}\right)$ than the augites observed in the 8-kbar experiments on ALV-1690-20, and the multiple saturation is therefore eutectic. In ALV-1690-20, because low-Ca pyroxene saturation occurs at a higher temperature $\left(1209^{\circ} \mathrm{C}\right)$, the augite has lower $\mathrm{Ca}$ content $\left(\mathrm{Wo}_{28} \mathrm{En}_{53}\right)$ and the multiple saturation is peritectic.

\section{DISCUSSION}

\section{Compositional variation in Serocki lavas}

We now discuss the compositional variations in Serocki lavas and their mineral phases, and interpret these variations using experimental constraints. Many sparsely phyric and

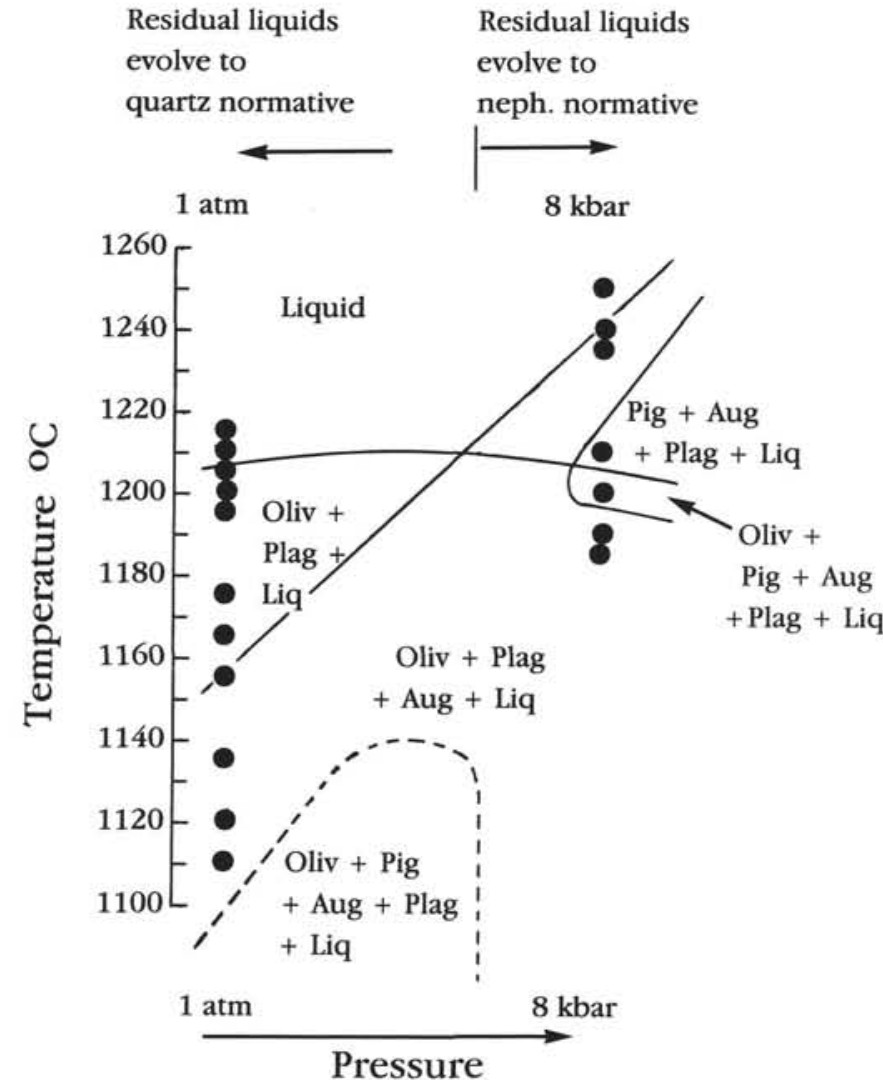

Figure 1. Results of experiments on Sample ALV-1690-20 from Serocki volcano, $22^{\circ} 55^{\prime} \mathrm{N}$, Mid-Atlantic ridge. Experiments at $1 \mathrm{~atm}$ were carried out at the QFM buffer using FePt alloy loops. 8-kbar experiments were done in a piston cylinder apparatus in FePt alloy and graphite capsules. Tables 2 and 3 contain run compositions and conditions. 
Table 3. Electron microprobe analyses of experimental run products. ${ }^{\mathrm{a}}$

\begin{tabular}{|c|c|c|c|c|c|c|c|c|c|c|c|c|c|}
\hline Run & Phase & $\begin{array}{l}\text { \# of } \\
\text { anals }\end{array}$ & $\mathrm{SiO}_{2}$ & $\mathrm{TiO}_{2}$ & $\mathrm{Al}_{2} \mathrm{O}_{3}$ & $\mathrm{FeO}$ & $\mathrm{MgO}$ & $\mathrm{MnO}$ & $\mathrm{CaO}$ & $\mathrm{K}_{2} \mathrm{O}$ & $\mathrm{Na}_{2} \mathrm{O}$ & $\mathrm{P}_{2} \mathrm{O}_{5}$ & Total \\
\hline 80 & gl & 7 & $50.0(2)$ & $1.66(4)$ & $15.7(1)$ & $10.2(2)$ & $7.78(9)$ & $0.14(4)$ & $11.0(1)$ & $0.13(2)$ & $3.07(8)$ & $0.16(3)$ & 99.8 \\
\hline 50 & gl & 7 & $50.0(2)$ & $1.67(4)$ & $15.7(1)$ & $10.3(2)$ & $7.76(12)$ & $0.14(2)$ & $11.1(1)$ & $0.13(2)$ & $3.03(9)$ & $0.14(3)$ & 100. \\
\hline \multirow[t]{3}{*}{40} & gl & 7 & $49.8(3)$ & $1.68(3)$ & $15.6(1)$ & $10.3(3)$ & $7.74(12)$ & $0.15(3)$ & $10.9(1)$ & $0.14(1)$ & $2.99(11)$ & $0.16(3)$ & 99.5 \\
\hline & $\mathrm{pl}$ & 3 & $49.9(2)$ & $b-$ & $31.1(1)$ & $0.67(3)$ & $0.27(1)$ & - & 14.9(1) & $0.03(1)$ & $3.03(4)$ & - & 99.9 \\
\hline & ol & 3 & $39.8(4)$ & $0.05(2)$ & $0.25(16)$ & $14.8(9)$ & $44.4(1.1)$ & $0.24(2)$ & $0.43(5)$ & - & - & - & 100.0 \\
\hline \multirow[t]{3}{*}{30} & gl & 7 & $49.9(3)$ & $1.69(1)$ & $15.6(3)$ & $10.3(2)$ & $7.80(9)$ & $0.15(3)$ & $10.9(1)$ & $0.14(2)$ & $2.92(7)$ & $0.16(3)$ & 99.6 \\
\hline & pl & 3 & $50.5(2)$ & - & $31.3(4)$ & $0.56(9)$ & $0.22(1)$ & - & $14.9(2)$ & 0.00 & $3.06(7)$ & - & 100.5 \\
\hline & ol & 5 & $39.7(2)$ & $0.03(1)$ & $0.05(3)$ & $16.0(3)$ & $43.9(3)$ & $0.22(1)$ & $0.35(2)$ & - & - & - & 99.5 \\
\hline \multirow[t]{3}{*}{20} & gl & 7 & $49.8(3)$ & $1.74(6)$ & $15.5(2)$ & $10.4(4)$ & $7.78(10)$ & $0.14(6)$ & $11.0(1)$ & $0.14(2)$ & $2.96(8)$ & $0.21(3)$ & 99.7 \\
\hline & $\mathrm{pl}$ & 3 & $49.7(3)$ & - & $30.8(4)$ & $0.73(1)$ & $0.37(9)$ & - & $14.9(1)$ & $0.03(1)$ & $2.96(12)$ & - & 100.2 \\
\hline & ol & 3 & $39.8(7)$ & $0.03(1)$ & $0.13(8)$ & $16.1(2)$ & $43.9(9)$ & $0.26(3)$ & $0.37(1)$ & - & - & - & 100.6 \\
\hline \multirow[t]{3}{*}{100} & gl & 7 & $50.2(2)$ & $2.00(5)$ & $14.2(1)$ & $11.0(1)$ & $7.30(8)$ & $0.25(2)$ & $11.1(5)$ & $0.20(2)$ & $2.64(5)$ & $0.23(3)$ & 99.1 \\
\hline & $\mathrm{pl}$ & 5 & $50.5(8)$ & - & $30.9(4)$ & $0.68(14)$ & $0.29(10)$ & - & $14.6(4)$ & $0.03(1)$ & $3.06(21)$ & - & 100.1 \\
\hline & ol & 3 & $39.4(3)$ & $0.06(2)$ & $0.06(1)$ & $18.0(2)$ & $42.7(8)$ & $0.31(2)$ & $0.39(1)$ & - & - & - & 101.0 \\
\hline \multirow[t]{3}{*}{110} & gl & 7 & $50.4(3)$ & $2.10(11)$ & $13.8(2)$ & $11.1(1)$ & $6.93(6)$ & $0.22(3)$ & $11.1(5)$ & $0.23(2)$ & $3.09(13)$ & $0.19(3)$ & 99.2 \\
\hline & $\mathrm{pl}$ & 5 & $51.3(2)$ & - & $30.0(1)$ & $0.63(7)$ & $0.22(3)$ & - & $13.7(1)$ & $0.05(1)$ & $3.57(12)$ & - & 99.5 \\
\hline & ol & 3 & $39.0(5)$ & $0.06(2)$ & $0.05(2)$ & $18.7(2)$ & $41.3(6)$ & $0.32(7)$ & $0.46(2)$ & - & - & - & 99.9 \\
\hline \multirow[t]{4}{*}{120} & gl & 8 & $49.9(13)$ & $2.37(6)$ & $13.2(2)$ & $11.7(2)$ & $6.52(16)$ & $0.26(4)$ & $10.9(1)$ & $0.26(3)$ & $2.99(7)$ & $0.21(1)$ & 98.3 \\
\hline & $\mathrm{pl}$ & 3 & $51.6(1)$ & - & $29.3(1)$ & $0.78(8)$ & $0.34(5)$ & - & $13.2(1)$ & $0.05(1)$ & $3.83(18)$ & - & 99.1 \\
\hline & ol & 3 & $38.8(3)$ & $0.06(1)$ & $0.19(2)$ & $20.4(1)$ & $39.6(6)$ & $0.32(2)$ & $0.57(12)$ & - & - & - & 100.0 \\
\hline & aug & 3 & $52.0(3)$ & $0.75(10)$ & $2.25(52)$ & $6.54(17)$ & $16.9(4)$ & $0.22(4)$ & $20.2(3)$ & - & 0.00 & - & 98.9 \\
\hline \multirow[t]{4}{*}{130} & gl & 8 & $50.2(2)$ & $2.90(3)$ & $12.7(1)$ & $12.9(3)$ & $5.94(10)$ & $0.25(4)$ & $10.1(2)$ & $0.35(4)$ & $3.19(11)$ & $0.24(3)$ & 98.8 \\
\hline & $\mathrm{pl}$ & 4 & $53.2(2)$ & - & $29.0(2)$ & $0.79(8)$ & $0.23(3)$ & - & $12.2(2)$ & $0.05(1)$ & $4.26(15)$ & - & 99.7 \\
\hline & ol & 3 & $38.8(2)$ & $0.07(2)$ & $0.08(2)$ & $23.8(1)$ & $37.2(2)$ & $0.39(5)$ & $0.49(3)$ & - & - & - & 100.9 \\
\hline & aug & 4 & $51.7(4)$ & $1.00(7)$ & $2.77(31)$ & $8.11(16)$ & $16.3(3)$ & $0.23(4)$ & $19.3(2)$ & - & $0.33(8)$ & - & 99.8 \\
\hline \multirow[t]{4}{*}{140} & $\mathrm{gl}$ & 8 & $49.2(2)$ & $3.69(10)$ & $12.0(1)$ & $14.3(3)$ & $5.46(12)$ & $0.30(4)$ & $9.61(24)$ & $0.41(3)$ & $3.13(12)$ & $0.26(2)$ & 98.4 \\
\hline & $\mathrm{pl}$ & 7 & $52.6(1.2)$ & - & $28.6(9)$ & $0.85(25)$ & $0.32(17)$ & - & $12.6(9)$ & $0.06(1)$ & $4.17(53)$ & - & 99.2 \\
\hline & ol & 8 & $37.3(3)$ & $0.08(4)$ & $0.06(5)$ & $27.6(5)$ & $33.6(5)$ & $0.42(3)$ & $0.48(4)$ & - & - & - & 99.6 \\
\hline & aug & 9 & $51.7(5)$ & $1.07(14)$ & $2.22(40)$ & $9.45(40)$ & $16.4(4)$ & $0.26(3)$ & $19.1(6)$ & - & $0.26(3)$ & - & 100.4 \\
\hline \multirow[t]{4}{*}{150} & gl & 9 & $48.3(4)$ & $5.07(20)$ & $11.2(2)$ & $15.8(4)$ & $4.93(11)$ & $0.33(4)$ & $9.23(7)$ & $0.61(6)$ & $2.82(15)$ & $0.33(2)$ & 98.6 \\
\hline & $\mathrm{pl}$ & 5 & $54.8(5)$ & - & $28.5(2)$ & $0.76(9)$ & $0.21(3)$ & - & $11.2(2)$ & $0.09((1)$ & $4.90(22)$ & - & 100.5 \\
\hline & ol & 4 & $37.3(3)$ & $0.12(3)$ & $0.06(3)$ & $30.3(1)$ & $31.9(2)$ & $0.46(3)$ & $0.51(3)$ & - & - & - & 100.7 \\
\hline & aug & 8 & $51.2(6)$ & $1.43(8)$ & $2.42(79)$ & $9.90(31)$ & $15.5(6)$ & $0.27(3)$ & $18.7(4)$ & - & $0.31(4)$ & - & 99.7 \\
\hline \multirow[t]{3}{*}{ H8 } & $\mathrm{gl}$ & 7 & $50.4(4)$ & $2.11(7)$ & $15.4(2)$ & $9.58(75)$ & $7.48(19)$ & $0.20(5)$ & $9.75(15)$ & $0.16(2)$ & $3.54(9)$ & $0.28(5)$ & 98.9 \\
\hline & $\mathrm{pl}$ & 4 & $53.7(3)$ & - & $28.5(6)$ & $0.78(22)$ & $0.34(12)$ & - & $11.9(2)$ & $0.03(1)$ & $4.73(6)$ & - & 100.0 \\
\hline & aug & 6 & $51.4(2)$ & $0.73(11)$ & $5.65(75)$ & $7.97(46)$ & $18.2(7)$ & $0.23(3)$ & $15.6(7)$ & - & $0.62(10)$ & - & 100.4 \\
\hline \multirow[t]{4}{*}{ H7 } & gl & 7 & $48.7(1)$ & $2.74(4)$ & $14.0(1)$ & $12.7(1)$ & $6.95(3)$ & $0.16(2)$ & $9.23(3)$ & $0.22(1)$ & $3.53(2)$ & $0.45(3)$ & 98.7 \\
\hline & $\mathrm{pl}$ & 5 & $53.6(3)$ & - & $28.5(2)$ & $0.73(3)$ & $0.19(1)$ & - & $11.7(2)$ & $0.06(1)$ & $4.89(14)$ & - & 99.7 \\
\hline & aug & 6 & $51.7(3)$ & $0.75(4)$ & $4.27(21)$ & $7.96(21)$ & $19.6(4)$ & $0.24(2)$ & $15.1(6)$ & - & $0.35(1)$ & - & 100.0 \\
\hline & pig & 6 & $54.6(2)$ & $0.26(2)$ & $1.73(54)$ & $10.9(2)$ & $26.9(6)$ & $0.28(2)$ & $5.27(54)$ & - & $0.15(5)$ & - & 100.1 \\
\hline \multirow[t]{5}{*}{$\mathrm{H} 10$} & $\mathrm{gl}$ & 7 & $48.6(8)$ & $2.55(19)$ & $13.9(2)$ & $13.9(7)$ & $6.56(9)$ & $0.21(2)$ & $8.90(9)$ & $0.22(2)$ & $3.52(14)$ & $0.34(5)$ & 98.7 \\
\hline & $\mathrm{pl}$ & 5 & $54.3(2)$ & - & $28.6(3)$ & $0.88(10)$ & $0.20(7)$ & - & $11.4(1)$ & $0.06(1)$ & $5.06(11)$ & - & 100.5 \\
\hline & aug & 4 & $51.2(1)$ & $0.79(9)$ & $5.47(65)$ & $10.9(3)$ & $18.1(5)$ & $0.27(2)$ & $13.7(5)$ & - & $0.58(9)$ & - & 100.6 \\
\hline & pig & 3 & $53.0(3)$ & $0.49(6)$ & $3.34(42)$ & $13.1(9)$ & $23.0(5)$ & $0.32(7)$ & $7.71(70)$ & - & $0.30(4)$ & - & 101.4 \\
\hline & ol & 1 & 38.9 & 0.09 & 0.19 & 22.3 & 37.6 & 0.33 & 0.64 & - & - & - & 100.01 \\
\hline \multirow[t]{4}{*}{$\mathrm{H} 47$} & gl & 10 & $\begin{array}{l}45.0 \\
(1.6)\end{array}$ & $\begin{array}{l}3.77 \\
(40)\end{array}$ & $\begin{array}{l}12.3 \\
(1.1)\end{array}$ & $\begin{array}{l}20.4 \\
\quad(3.2)\end{array}$ & $\begin{array}{l}4.37 \\
(1.1)\end{array}$ & $\begin{array}{r}0.32 \\
(5)\end{array}$ & $\begin{array}{c}8.24 \\
(48)\end{array}$ & $\begin{array}{l}0.40 \\
\quad(12)\end{array}$ & $\begin{array}{l}4.02 \\
(44)\end{array}$ & $\begin{array}{c}0.44 \\
\text { (11) }\end{array}$ & 99.3 \\
\hline & $\mathrm{pl}$ & 6 & $54.2(4)$ & - & $27.4(6)$ & $0.69(21)$ & $0.48(31)$ & - & $11.4(1)$ & $0.11(1)$ & $5.98(8)$ & - & 100.3 \\
\hline & aug & 12 & $50.8(8)$ & $1.29(21)$ & $3.90(58)$ & $10.7(1.5)$ & $17.4(1.3)$ & $0.27(5)$ & $14.1(1.6)$ & - & $0.53(13)$ & - & 99.0 \\
\hline & ol & 3 & $37.5(4)$ & $0.11(1)$ & $0.07(1)$ & $25.5(2)$ & $36.2(3)$ & $0.35(1)$ & $0.43(3)$ & - & - & - & 100.2 \\
\hline
\end{tabular}

${ }^{\text {a }}$ Units in parentheses represent one standard deviation of replicate analyses in terms of least units cited. Thus, $50.0(2)$ should be read as $50.0 \pm 0.2$.

${ }^{b}$ Element not analyzed.

phyric KFZ lavas represent magmatic liquid compositions, which have undergone within-sample differentiation (Bryan et al., 1981). In such lavas the phenocrysts are preserved in near equilibrium proportions, the glass is a residual liquid, and the bulk rock is therefore a liquid composition which has neither lost nor gained crystals. Low pressure experimental data can be used to test whether the lava has retained phenocrysts in equilibrium proportions (Tormey et al., 1987). In the case of the sparsely phyric lavas from Serocki volcano, An-rich disequilibrium plagioclase phenocrysts are present (Detrick et al., 1988) and some plagioclase accumulation may have occurred.

An average of WHOI XRF whole rock analyses and Smithsonian electron microprobe analyses of glasses from the Hole 648B drill core and the Alvin dive to Serocki (Humphris et al., this volume) are tabulated in Table 4 along with the composition of a calcic plagioclase phenocryst. The same analytical data set including MIT electron microprobe analyses of glass is shown for all lavas from the Serocki area in
Figure 5 on $\mathrm{CaO}-\mathrm{MgO}$ and $\mathrm{Al}_{2} \mathrm{O}_{3}-\mathrm{MgO}$ variation diagrams. The Serocki rock analyses are generally higher in $\mathrm{CaO}$ and $\mathrm{Al}_{2} \mathrm{O}_{3}$ than the glass analyses, but there is a small region of overlap in the glass and whole rock fields. Apparently, among the samples chosen for analysis, some variation in phenocryst content has occurred, and samples with fewer phenocrysts are correspondingly closer to some glass compositions. However, there is an overall consistency in the percent phenocrysts in the Serocki lavas, and most of the samples from the volcano contain about $2 \%-4 \%$ phenocrysts (Detrick et al., 1988). Most of the glass analyses plot as a coherent group at $\mathrm{CaO}, \mathrm{Al}_{2} \mathrm{O}_{3}$, and $\mathrm{MgO}$ contents comparable to or slightly lower than the whole rock analyses. The four glass points (Fig. 5) plotting at higher $\mathrm{CaO}, \mathrm{Al}_{2} \mathrm{O}_{3}$, and $\mathrm{MgO}$ contents are analyses of an older lava which underlies Serocki volcano (ALV-1690-17).

The 1-atm experimental liquid line of descent determined for ALV-1690-20 is also plotted for comparison. Oliv + plag crystallization in weight proportions $25: 75$, respectively, produces an enrichment in $\mathrm{CaO}$ and a depletion in $\mathrm{Al}_{2} \mathrm{O}_{3}$ as $\mathrm{MgO}$ 


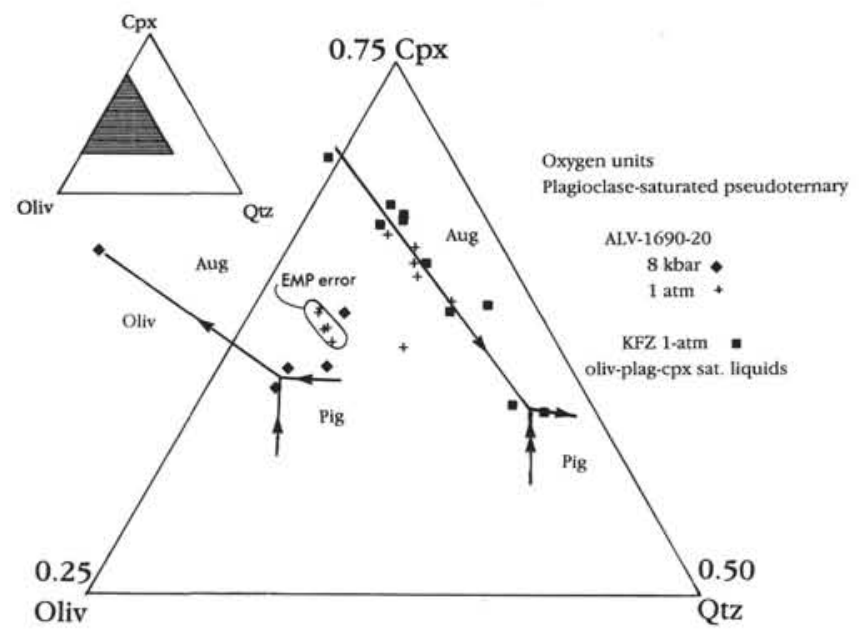

Figure 2. Compositions of liquids produced in 1-atm (pluses) and 8-kbar (diamonds) melting experiments on Sample ALV-1690-20 projected into the Oliv-Cpx-Qtz pseudoternary. Projection uses oxygen units and the recalculation of Tormey et al. (1987). A part of the triangle (shown as shaded area) has been expanded. The EMP error represents a $2 \sigma$ error ellipse for MIT electron microprobe analyses of ALV-1690-20 starting material. Also shown (squares) are the Tormey et al. (1987) experiments which define the 1-atm oliv-cpx-plag multiple saturation boundary and the low-Ca pyroxene saturation for other selected KFZ compositions.

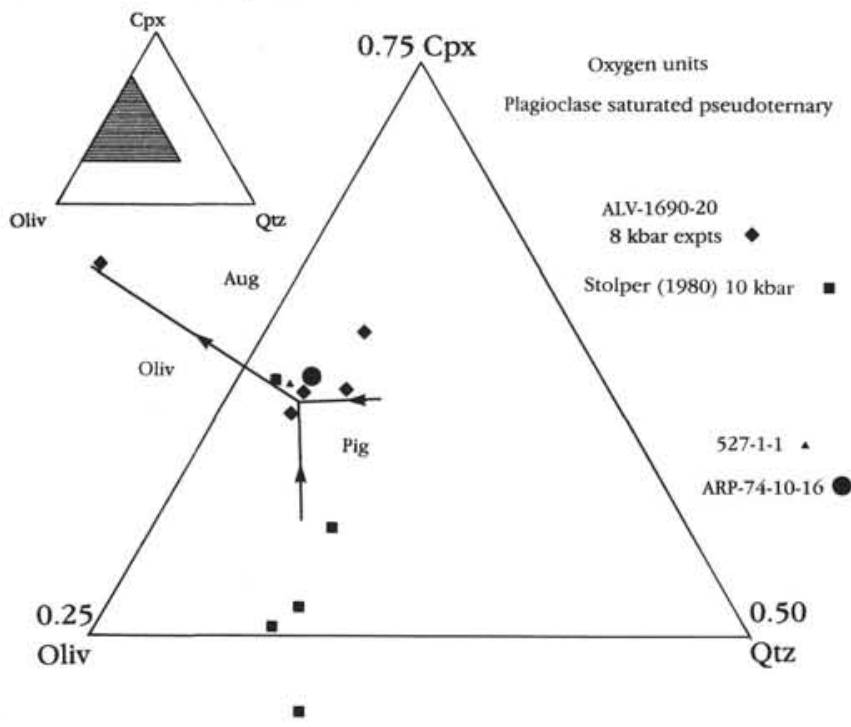

Figure 3. Comparison of the projected positions of multiply saturated liquids from experiments on Sample ALV-1690-20 with multiply saturated liquids from other 8- and 10-kbar experiments on MORB compositions. Boundary curves are drawn based on the experiments on ALV-1690-20. Dark circle is the bulk composition of ARP74-10-16. This MORB is nearly multiply saturated with oliv, opx, aug, and plag at 10 kbar (Fujii and Bougault, 1983). The triangle is the liquid from the Bender et al. (1978) 10-kbar experiment on 527-1-1 which is saturated with oliv, aug, and plag. The squares are liquid compositions from the 10-kbar experiments of Stolper (1980). Four of the points are oliv + opx saturated and the single liquid that projects near the oliv + aug + plag boundary is saturated with these phases.

decreases and temperature drops. When augite appears as a crystallizing phase, $\mathrm{CaO}$ and $\mathrm{Al}_{2} \mathrm{O}_{3}$ both decrease with decreasing $\mathrm{MgO}$ and temperature. The experiments (analyzed on the MIT electron microprobe) do not pass through the center of the data cluster (analyzed on both the Smithsonian electron micro-

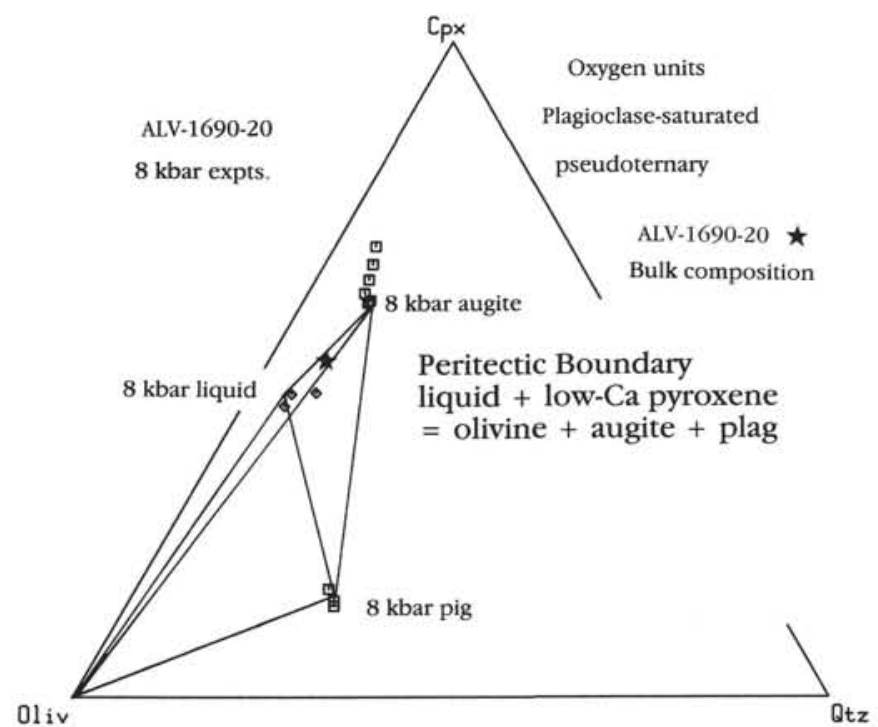

Figure 4. Projected compositions of augite, pigeonite (pig), and liquid in the multiply saturated liquid from 8-kbar ALV-1690-20 experiments.

Table 4. Analyses of whole rock, glass, and phenocrysts from the Serocki area used in materials balance calculations.

\begin{tabular}{lrrrccc}
\hline & \multicolumn{1}{c}{1} & \multicolumn{1}{c}{2} & \multicolumn{1}{c}{3} & \multicolumn{1}{c}{4} & 5 & 6 \\
\hline $\mathrm{SiO}_{2}$ & 49.89 & 50.14 & 50.21 & 50.12 & 47.2 & 52.9 \\
$\mathrm{Al}_{2} \mathrm{O}_{3}$ & 16.24 & 15.81 & 16.40 & 15.88 & 32.9 & 29.0 \\
$\mathrm{TiO}_{2}$ & 1.68 & 1.72 & 1.42 & 1.78 & - & - \\
$\mathrm{FeO}$ & 9.78 & 10.03 & 9.29 & 9.98 & 0.33 & 0.66 \\
$\mathrm{MgO}$ & 7.60 & 7.57 & 8.16 & 7.33 & 0.20 & 0.28 \\
$\mathrm{CaO}$ & 11.34 & 11.13 & 11.48 & 11.08 & 17.0 & 12.5 \\
$\mathrm{Na}_{2} \mathrm{O}$ & 2.82 & 2.96 & 2.85 & 2.97 & 1.68 & 4.40 \\
$\mathrm{~K}_{2} \mathrm{O}$ & 0.16 & 0.15 & 0.13 & 0.13 & 0.01 & 0.05 \\
$\mathrm{P}_{2} \mathrm{O}_{5}$ & 0.17 & 0.17 & 0.16 & 0.17 & - & - \\
$\mathrm{Sum}$ & 99.44 & 100.10 & 99.82 & 99.74 & 99.32 & 99.79 \\
$\mathrm{An}$ & & & & & 84.5 & 61.0 \\
$\mathrm{Mg} \#$ & & & & & 0.52 & 0.44 \\
\hline
\end{tabular}

1. Average of all whole rock XRF data from Serocki volcano, WHOI. Includes Site 648 and Alvin samples.

2. Average of all glass analyses from Serocki, Smithsonian electron microprobe. Includes Site 648 and Alvin samples.

3. Glass analysis from Sample ALV-1690-17 of older lava underlying Serocki volcano, Smithsonian electron microprobe.

4. Glass analysis from Sample ALV-1690-2. This sample is representative of the "evolved" end of Serocki lava compositional spectrum, Smithsonian electron microprobe.

5. Core of calcic plagioclase xenocryst from Sample 648B15R-1, 75-79 cm, MIT electron microprobe.

6. Overgrowth rim on calcic plagioclase xenocryst from Sample $648 \mathrm{~B}-15 \mathrm{R}-1,75-79 \mathrm{~cm}$, MIT electron microprobe.

probe and the MIT electron microprobe) in Figure 5. Instead, the experimental data cluster near the glass analyses of Hole 648B lavas (Detrick et al., 1988) made at MIT. Among the remaining glass analyses which cluster at $\mathrm{CaO}, \mathrm{Al}_{2} \mathrm{O}_{3}$, and $\mathrm{MgO}$ contents comparable to or lower than the rock analyses, there is a small systematic difference between the MIT and Smithsonian electron microprobe data. The MIT glass analyses are higher in $\mathrm{MgO}$ and lower in $\mathrm{Al}_{2} \mathrm{O}_{3}$, compared to the Smithsonian analyses. The compositional differences between whole rocks and glasses are also small, but lie outside the analytical uncertainties in both techniques ( $2 \sigma$ errors are shown in Fig. 5 for XRF and in Fig. 6 for both XRF and EMP). The Serocki whole rock analyses are 

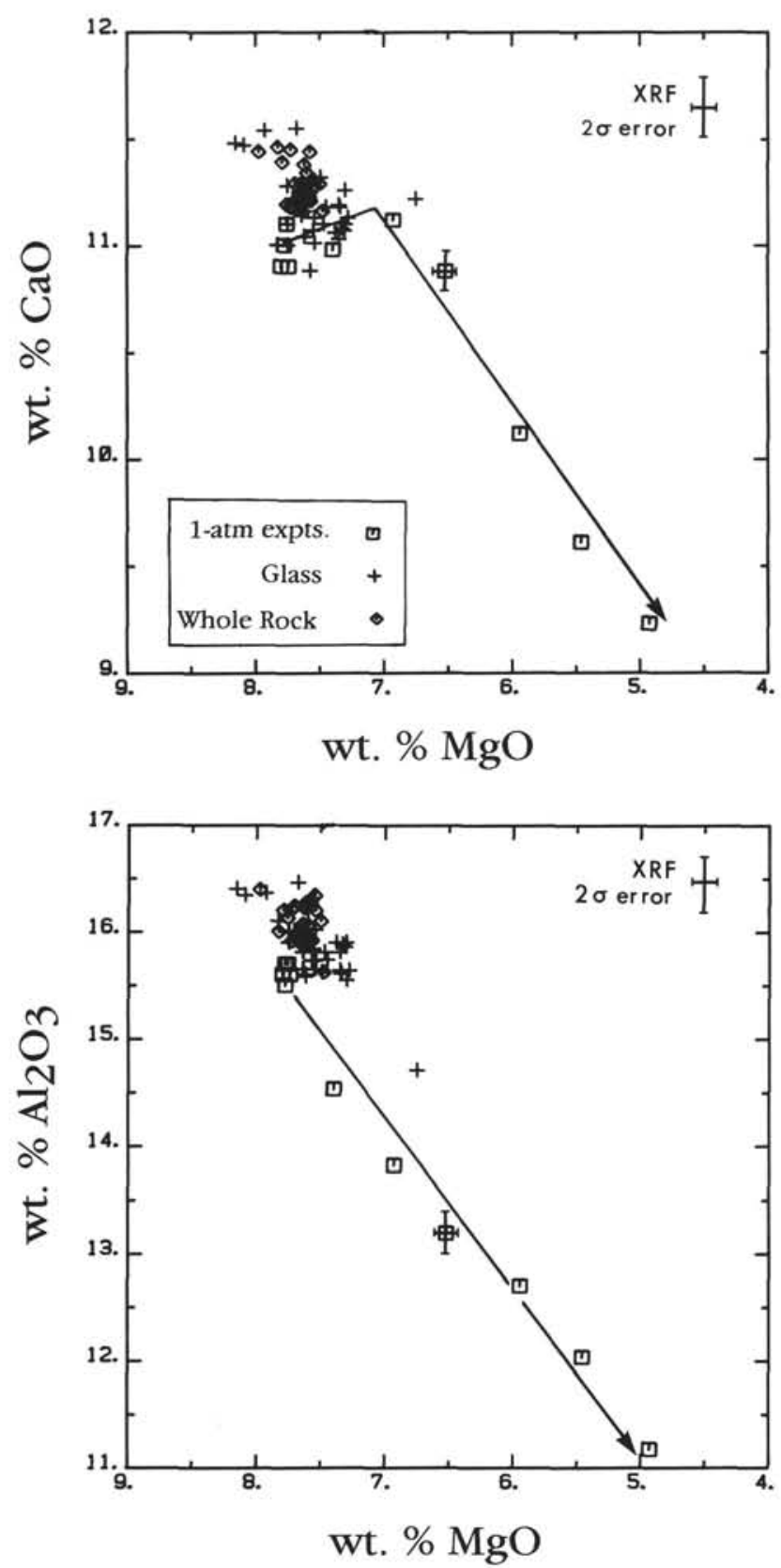

Figure 5. $\mathrm{CaO}$ vs. $\mathrm{MgO}$ and $\mathrm{Al}_{2} \mathrm{O}_{3}$ vs. $\mathrm{MgO}$ variation diagrams for Serocki Volcano whole rock (diamonds), glass (pluses), and ALV1690-20 1-atm glass (squares) compositions. The magnitude of $2 \sigma$ errors in WHOI glass analyses is shown in the upper right corner of each diagram. The typical $2 \sigma$ errors on MIT glass analyses are shown for a single composition at $6.5 \mathrm{wt} . \% \mathrm{MgO}$. The solid line is drawn by eye through the 1-atm glasses and shows the liquid line of descent followed during crystallization.

generally higher in $\mathrm{CaO}$ and $\mathrm{Al}_{2} \mathrm{O}_{3}$ at about equivalent $\mathrm{MgO}$ contents compared to both the Smithsonian and MIT glass analyses. This glass-whole rock separation is most evident in the $\mathrm{CaO}-\mathrm{MgO}$ variation diagram, where it crosses the 1 -atm oliv + plag crystallization boundary. The glass-whole rock trend does not lie along a path followed by 1 -atm near-liquidus fractionation of oliv + plag.

A series of calculations were done to mass balance the average Serocki whole rock and average Serocki glass, 1-atm
Table 5. Results of materials balance calculations for within-sample and within-area differentiation.

\begin{tabular}{|c|c|c|c|c|c|c|}
\hline & \multicolumn{2}{|c|}{1} & \multicolumn{2}{|c|}{2} & \multicolumn{2}{|c|}{3} \\
\hline & \multicolumn{2}{|c|}{$\overline{\text { Calc. - Obs. }}$} & \multicolumn{2}{|c|}{$\overline{\text { Calc. - Obs. }}$} & \multicolumn{2}{|c|}{ Calc. - Obs. } \\
\hline $\mathrm{SiO}_{2}$ & 49.92 & 49.89 & 50.17 & 50.21 & 50.39 & 50.21 \\
\hline $\mathrm{Al}_{2} \mathrm{O}_{3}$ & 16.25 & 16.24 & 16.64 & 16.40 & 16.18 & 16.40 \\
\hline $\mathrm{TiO}_{2}$ & 1.65 & 1.68 & 1.60 & 1.42 & 1.53 & 1.42 \\
\hline $\mathrm{FeO}$ & 9.73 & 9.78 & 9.52 & 9.29 & 9.13 & 9.29 \\
\hline $\mathrm{MgO}$ & 7.59 & 7.60 & 8.12 & 8.16 & 8.05 & 8.16 \\
\hline $\mathrm{CaO}$ & 11.24 & 11.34 & 11.10 & 11.48 & 11.13 & 11.48 \\
\hline $\mathrm{Na}_{2} \mathrm{O}$ & 2.89 & 2.82 & 2.90 & 2.85 & 2.96 & 2.85 \\
\hline $\mathrm{K}_{2} \mathrm{O}$ & 0.14 & 0.16 & 0.12 & 0.13 & 0.11 & 0.13 \\
\hline $\mathrm{P}_{2} \mathrm{O}_{5}$ & 0.16 & 0.17 & 0.15 & 0.16 & 0.14 & 0.16 \\
\hline$\Sigma R^{2}$ & 0.02 & & 0.28 & & 0.26 & \\
\hline Liquid & 0.96 & & 0.90 & & 0.84 & \\
\hline Olivine & 0.01 & & 0.03 & & 0.02 & \\
\hline Plag & 0.03 & & 0.07 & & 0.09 & \\
\hline Augite & & & & & 0.05 & \\
\hline
\end{tabular}

Phase compositions used as input for materials balance calculations.

1. This model tests within-sample differentiation for Serocki lavas, using average compositions of whole rock and glass and two choices of mineral phases. Calculation above used average Serocki whole rock and glass (Table 4, \#1 and 2), 1-atm liquidus olivine (Table 3, run 40) and $\mathrm{An}_{84}$ plag (Table 4. \#5). A second materials balance model which used the 1 -atm liquidus plag (Table 2, run 40) gave $\mathrm{SR}^{2}=0.06$.

2. This model tests for a fractional crystallization relation between two spatially associated lavas represented by ALV1690-17, an older, underlying, more mafic lava, and ALV$1690-2$, an evolved glass composition from Serocki volcano. Calculation above used ALV-1690-17 as parent, ALV-16902 as derivative liquid and 1 -atm olivine and plagioclase (Table 3, run 40 ) as residual phases. A second materials balance model which used a calculated 1-atm augite gave $\Sigma \mathrm{R}^{2}=0.02$.

3. This model tests for a high pressure fractional crystallization relation between ALV-1690-17 and ALV-1690-2. Calculation used ALV-1690-17 as parent, ALV-1690-2 as derivative liquid and 1-atm olivine (Table 3, run 40), 8 kbar plagioclase and 8 kbar augite (Table 3 , run $\mathrm{H} 10$ ) as residual phases.

liquidus phases (oliv + plag) and the $\mathrm{An}_{84}$ plagioclase phenocrysts. The models recover the whole rock composition using the glass as residual liquid and combinations of minerals present in the lavas. The model which most successfully accounted for the bulk rock composition used the 1-atm liquidus olivine, $\mathrm{An}_{84}$ plagioclase, and residual glass (model \#1, Table 5). Models which used only the 1-atm liquidus phases produced poorer fits (Table 5 , footnote). The mass balance is consistent with petrographic observation. Disequilibrium plagioclase phenocrysts are common in the lavas along with olivine as glomerocrystic aggregates and this pair provides the best fit.

The mass balance also predicts $4 \mathrm{wt} \%$ crystals in wt. proportions $25 \%$ oliv and $75 \%$ disequilibrium plag, which is equivalent to the 1-atm equilibrium phase proportions in the Serocki (Table 2) and other MORB liquids (Grove and Bryan, 1983; Tormey et al., 1987). The phase assemblage has the appropriate proportions of oliv + plag for a lava which crystallized at near ocean floor conditions, but the $A_{84}$ plagioclase is not in equilibrium with Serocki liquid. Equilibrium plagioclase at $1 \mathrm{~atm}$ should be $\mathrm{An}_{72}$ (Table 3). We have no explanation for this result, other than it must be a coincidence. Phenocryst abundance in Serocki lavas varies from 1 to 10 vol.\% (Detrick et al., 1988), which is consistent with plagioclase accumulation. Cooling rate experiments (Grove, this volume) indicate that Serocki lava cooled on the seafloor from an initial temperature slightly above its liquidus, further supporting the disequilibrium character of the plagioclase phenocrysts. 




Figure 6. Compositions of Serocki area whole rock and glass projected on the Oliv-Cpx-Qtz pseudoternary. Symbols are as in Figure 5. Two $\sigma$ error ellipses are shown for WHOI XRF and MIT electron microprobe analyses.

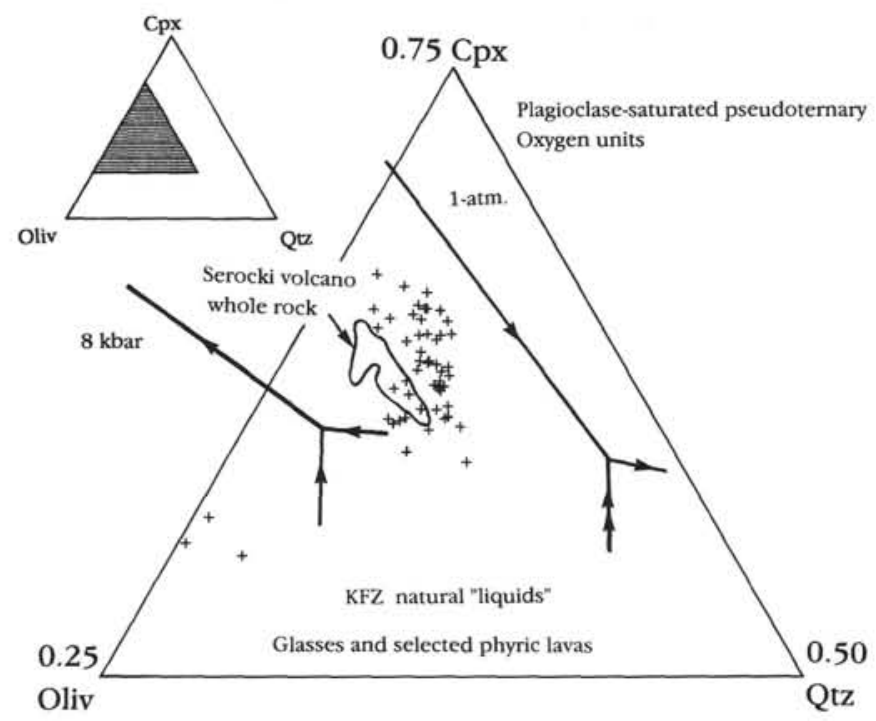

Figure 7. A subset of KFZ lavas and glasses which Tormey et al. (1987) recognized as magmatic liquid compositions and the field of the Serocki whole rock compositions plotted in Figure 6 are shown in the Oliv-Cpx-Qtz pseudoternary. Also shown are the 1-atm and 8-kbar saturation boundaries from ALV-1690-20 experiments.

\section{Elevated Pressure Fractionation at Serocki and in other KFZ MORB suites}

The lavas from the Kane Fracture Zone region (Bryan et al., 1981; Tormey et al., 1987) sample an $80-\mathrm{km}$ segment of mid-Atlantic ridge, and exhibit geochemical characteristics which indicate differences in the mantle sources over this region. For example, the ${ }^{87 / 86} \mathrm{Sr}$ and ${ }^{143 / 144} \mathrm{Nd}$ isotopic differences between the lavas in the north and south rifts (Machado et al., 1983) indicate distinctive mantle reservoirs for these two ridge segments. Within suites of KFZ lavas collected from restricted geographic areas there are coherent geochemical trends in major and trace elements, and these variations are referred to as within-site variations (Bryan et al., 1981). Tormey et al. (1987) discuss several suites of lavas from restricted regions in the rift valley south of the $\mathrm{KFZ}$, and identify chemical variations that may be caused by fractional crystallization at elevated pressure. In the context of the Serocki area, within-site variation exists between the lavas of Serocki and the underlying older lava flow. The older underlying flow is less-evolved, and may represent the parent composition to the Serocki lavas. In the following series of mass balance calculations the most mafic of the analyzed lavas from this older flow is chosen as representative of a parent composition, and an evolved Serocki glass composition is chosen as representative of the derivative lava (Table 4, \#3). By choosing glass analyses for this discussion, we avoid the problem of plagioclase accumulation that could affect lava composition. The parental end of the compositional spectrum is characterized by the highest $\mathrm{MgO}, \mathrm{CaO}$, and $\mathrm{Al}_{2} \mathrm{O}_{3}$ contents (Fig. 5). In the Oliv-Cpx-Qtz (Fig. 6) and Oliv-Plag-Qtz pseudoternary projections the Serocki area lavas show an elongate trend away from the Oliv-Plag-Cpx base of the pseudoquaternary toward quartz. The extremes in the pseudoternary trends are the result of uncertainties in analytical abundances of $\mathrm{Na}_{2} \mathrm{O}$ and $\mathrm{SiO}_{2}$, which are magnified by this projection technique. We have plotted a $2 \sigma$ error ellipse for Serocki lavas calculated in a manner similar to that of Presnall and Hoover (1984). The high and low Qtz extremes in Figure 6 correspond to lavas with highest $\mathrm{SiO}_{2}$ and lowest $\mathrm{Na}_{2} \mathrm{O}$ and lavas with lowest $\mathrm{SiO}_{2}$ and highest $\mathrm{Na}_{2} \mathrm{O}$, respectively, and the spread is about that of the calculated $2 \sigma$ error ellipse. There are no other correlated differences in major or minor elements for these extreme compositions. The difference in projected position for the parent and derivative within-site extremes is small but much larger than analytical error for $\mathrm{MgO}, \mathrm{FeO}, \mathrm{Al}_{2} \mathrm{O}_{3}, \mathrm{TiO}_{2}$, and $\mathrm{CaO}$. However, when the parent and derivative are plotted on the pseudoternary, the two extremes lie within the large elliptical scatter caused by $\mathrm{SiO}_{2}$ and $\mathrm{Na}_{2} \mathrm{O}$ uncertainty. The mafic parent has a lower Qtz value and the derivative lava has a higher Qtz value, consistent with low pressure fractionation $(<5-6 \mathrm{kbar}$, based on our experiments).

Table 5 presents the results of a series of mass balance calculations designed to test the parent-derivative relationship between the older, underlying, less-evolved lavas and the more evolved Serocki lavas. A model which assumes fractionation of oliv + plag at 1 atm from the older, more mafic underlying lava as the process which generated the Serocki lavas as derivative (Table 5, model \#2) results in a poor fit with a high $\Sigma \mathrm{R}^{2}$. A model which included 1-atm augite produced a better fit (Table 5, footnote), but the compositional trend from parent to derivative glass is far removed from the 1-atm boundary in pseudoternary projections (Figs. 6 and 7). Therefore, low pressure, near ocean floor crystallization does not relate the parent and derivative lavas. The elevated pressure experimental results presented above allow us to test moderate pressure fractional crystallization models to relate the postulated parent and derivative lavas, and to quantify the depth at which such fractionation may have occurred. The positions of the 1-atm and 8-kbar oliv-aug-plag and olivaug-plag-pig boundaries are plotted in Figure 7 on the OlivCpx-Qtz pseudoternary along with the compositional field of Serocki area lavas. Also shown are the projected compositions of the phyric and sparsely phyric lavas from the Kane region which Tormey et al. (1987) identify as liquid compositions. The pressure of differentiation is estimated by assuming a linear change in the position of the oliv-aug-plag and low-Ca saturation boundary with pressure, and lies in the range of 5-6 kbar. Fractionation at this pressure involves oliv + aug + plag and the evolution from parent to derivative involves a slight increase in Qtz component. A materials balance model (Table 
5 , model \#3) relates the parent underlying glass (ALV$1690-17$ ) to the derivative Serocki glass (ALV-1690-2) by removing a high pressure augite and plagioclase (compositions were taken from the 8-kbar experiments) and an olivine calculated as the average of olivines in equilibrium with the parent and derivative. The materials balance is only approximate, since it is beyond our current state of knowledge to predict the compositions of augite at 5 and $6 \mathrm{kbar}$. The phase proportions are reasonably consistent with those determined experimentally at elevated pressure.

\section{Significance of plagioclase in Serocki lavas}

The plagioclase phenocrysts in Serocki lavas are not in equilibrium with a liquid of Serocki composition at any pressure under anhydrous conditions. The experimentally determined $\mathrm{Ca}-\mathrm{Na}$ mineral-melt distribution coefficient $\left(\mathrm{K}_{\mathrm{D}}{ }^{\mathrm{Ca}-\mathrm{Na}}=\left[\mathrm{X}_{\mathrm{Ca}}{ }^{\mathrm{Xtl}} * \mathrm{X}_{\mathrm{Na}}{ }^{\mathrm{Liq}}\right] /\left[\mathrm{X}_{\mathrm{Na}}{ }^{\mathrm{Xtl}} * \mathrm{X}_{\mathrm{Ca}}{ }^{\mathrm{Liq}}\right]\right)$ is $1.13 \pm 0.07$ at 1 atm and $0.91 \pm 0.08$ at $8 \mathrm{kbar}$ (these plagioclase $\mathrm{K}_{\mathrm{D}}$ 's are calculated from experimental data in Table 3 , and the errors represent one standard deviation of the mean). At 1 atm the liquidus plagioclase would be $\mathrm{An}_{72-69}$, and plagioclase microphenocrysts and rim compositions of phenocrysts $\left(\mathrm{An}_{65-70}\right)$ represent this compositional range (Meyer and Shibata, this volume). At $8 \mathrm{kbar}$ the liquidus plagioclase would be $\mathrm{An}_{66-62}$. Therefore, the effect of increased pressure on plagioclase composition is to make the plagioclase more Na-rich. This effect is in accord with elevated pressure experimental results in the system Anorthite-Albite (Lindsley, 1970). Assuming that water was not involved as a volatile component in the magmatic processes, the plagioclase could be relict from multiphase crystallization in the plag stability field of an $\mathrm{Mg}$-rich magma parental to the Serocki area lavas, or relict from a low- $\mathrm{Na}_{2} \mathrm{O}$ liquid which was mixed into a higher $\mathrm{Na}_{2} \mathrm{O}$ liquid to produce Serocki lava.

The $\mathrm{Ca} \#(\mathrm{Ca} /[\mathrm{Ca}+\mathrm{Na}])$ and $\mathrm{Mg} \#$ of the liquid which crystallized plagioclase can be estimated if the $\mathrm{K}_{\mathrm{D}}$ 's for $\mathrm{Ca}-\mathrm{Na}$ and $\mathrm{Fe}-\mathrm{Mg}$ are known and if the $\mathrm{Ca} \#$ and $\mathrm{Mg} \#$ of plagioclase are measured. From the discussion above the calculated $\mathrm{Ca}^{\#}$ of the liquid in equilibrium with $\mathrm{An}_{84}$ at $1 \mathrm{~atm}$ and $8 \mathrm{kbar}$ would be 0.84 and 0.86 , respectively. The plagioclase-liquid $\mathrm{Fe}-\mathrm{Mg}$ exchange $\mathrm{K}_{\mathrm{D}}\left(\mathrm{K}_{\mathrm{D}}{ }^{\mathrm{Fe}-\mathrm{Mg}}=\left[\mathrm{X}_{\mathrm{Fe}}{ }_{\mathrm{Xtl}} * \mathrm{X}_{\mathrm{Mg}}^{\mathrm{Liq}}\right] /\left[\mathrm{X}_{\mathrm{Mg}} \mathrm{Xtl}^{\mathrm{ta}} * \mathrm{X}_{\mathrm{Fe}}{ }^{\mathrm{Liq}}\right]\right)$ has been calibrated by Longhi et al. (1976) for lunar liquids, and we have averaged our experimental results to predict this $\mathrm{K}_{\mathrm{D}}$ for Serocki lavas crystallized near the QFM buffer. For the 1-atm and 8-kbar experiments, the value is the same within error and $\mathrm{K}_{\mathrm{D}}=1.74 \pm$ 0.09 . The $\mathrm{Mg} \#$ of a liquid in equilibrium with the $\mathrm{An}_{84}$ is therefore 0.65 .

A liquid with high $\mathrm{Ca} \#$ and $\mathrm{Mg} \#$ might have been parental to the Serocki suite, and crystallization at elevated pressures involving aug + plag, oliv + aug + plag or oliv + aug + plag + pig would produce an evolved Serocki derivative from such an $\mathrm{Mg}$-rich parent. We do not have experimental data of a quality sufficient to test this idea rigorously, but the simultaneous crystallization of augite and plagioclase would rapidly decrease the $\mathrm{Ca \#}$ of the parent liquid. Multiphase crystallization of plagioclase, augite, and olivine at 5-6 kbar, would involve dominantly plagioclase and augite (phase proportions at $8 \mathrm{kbar}$ are 0.53 plag : 0.44 aug : 0.03 oliv). Crystallization of this assemblage would cause a dramatic change in $\mathrm{Ca}^{\#}$ with decreasing $\mathrm{Mg} \#$.

The second alternative, magma mixing, requires the existence at the time of eruption of two magmas below Serocki, one with high $\mathrm{Ca \#}$ and $\mathrm{Mg \#}$ and the second with lower $\mathrm{Ca \#}$. There are ocean floor basalts with characteristics of the first type, but none have been sampled in the vicinity of Serocki or the Kane Fracture Zone. The closest candidate was sampled in dredges AII96-14,15 and GS104-17,20 (Bryan et al., 1981) from the west wall of the south rift, at the Ridge-Transform Fault intersection. These lavas have $\mathrm{a} \mathrm{Ca \#}=0.74$ and $\mathrm{Mg} \#=$ 0.61 , values that are closer, but not an exact match. The morphology and zoning patterns of olivine in plagioclase phenocrysts support a mixing event (Meyer and Shibata, this volume), but the mixing argument is weakened by the absence of the Na-rich plagioclase phenocrysts which would be associated with the higher $\mathrm{Na}_{2} \mathrm{O}$ component of the mix and which should also be present in the mixed magma.

\section{CONCLUSIONS}

Compositional variation among lavas from Serocki volcano is consistent with a small amount of both olivine crystallization of equilibrium composition and accumulation of $\mathrm{An}_{84}$ plagioclase, which is present as a xenocryst in variable abundance in the lavas. The $\mathrm{An}_{84}$ plagioclase xenocrysts in Serocki lavas can not be in equilibrium with a magma of Serocki composition at any pressure under anhydrous conditions. The plagioclase could be relict from multiphase crystallization of a liquid with high $\mathrm{Ca} \#$ and $\mathrm{Mg} \#$, or may be relict from a mixing event involving low- $\mathrm{Na}_{2} \mathrm{O}$ and high $\mathrm{Na}_{2} \mathrm{O}$ magmas. If mixing was the process that generated the Serocki lavas, then the compositional variation may have no significance as an indicator of elevated pressure fractionation. If fractional crystallization produced the compositional variation displayed by lavas from Serocki volcano and an older more mafic flow, the process involved plag + aug + oliv and occurred at approximately 5-6 kbar.

\section{ACKNOWLEDGMENTS}

The authors thank M. Fisk, P. Meyer, and D. Walker for reviews of the manuscript. S. Recca expertly maintained the MIT electron microprobe facility where the glasses and experimental run products were analyzed. This research was supported by NSF OCE-8609961.

\section{REFERENCES}

Albee, A. L., and Ray, L., 1970. Correction factors for electron microprobe analysis of silicates, oxides, carbonates, phosphates and sulfates. Anal. Chem., 42:1408-1414.

Baker, D. R., and Eggler, D. H., 1987. Compositions of anhydrous and hydrous melts coexisting with plagioclase, augite and olivine or low-Ca pyroxene from $1 \mathrm{~atm}$ to $8 \mathrm{kbar}$ : Application to the Aleutian volcanic center of Atka. Am. Mineral., 72:12-28.

Basaltic Volcanism Study Project, 1981. Basaltic Volcanism on the Terrestrial Planets. New York, (Pergamon), $1286 \mathrm{p}$.

Bence, A. E., and Albee, A. L., 1968. Empirical correction factors for the electron microanalysis of silicates and oxides. J. Geol., 76:382-403.

Bender, J. F., Hodges F. N., and Bence, A. E., 1978, Petrogenesis of basalts from the project FAMOUS area: Experimental study from 0 to 15 kbars. Earth Planet. Sci. Lett., 41:277-302.

Biggar, G. M., 1984. The composition of diopside solid solutions, and of liquids, in equilibrium with forsterite, plagioclase, and liquid in the system $\mathrm{Na}_{2} \mathrm{O}-\mathrm{CaO}-\mathrm{MgO}-\mathrm{Al}_{2} \mathrm{O}_{3}-\mathrm{SiO}_{2}$ and in remelted rocks from 1 bar to 12 kbar. Mineral. Mag., 48:481-94.

1972. Diopside, lithium metasilicate and the 1968 temperature scale. Mineral. Mag., 38:768-770.

Boyd, F. R., and England, J. L., 1960. Apparatus for phase equilibrium studies at pressures up to $50 \mathrm{kbars}$ and temperatures up to $1750^{\circ} \mathrm{C}$. J. Geophys. Res., 65:741-748.

Bryan, W. B., Finger, L. W., and Chayes, F., 1969. Estimating proportions in petrographic mixing equations by least squares approximation. Science, 163:926-927.

Bryan, W. B., Thompson, G., and Ludden, J. N., 1981. Compositional variation in normal MORB from $22^{\circ}-25^{\circ} \mathrm{N}$; Mid-Atlantic Ridge and Kane Fracture Zone. J. Geophys. Res., 86:11815-11836.

Detrick, R., Honnorez, J., Bryan, W. B., Juteau, T., et al., 1988. Proc. ODP, Init. Repts., 106/109: College Station, TX (Ocean Drilling Program). 
Fujii, T., and Bougault, H., 1983. Melting relations of a magnesian abyssal tholeiite and the origin of MORBs. Earth Planet. Sci. Lett., 62:283-295.

Green, D. H., Hibberson, W. O., and Jacques, A. L., 1979. Petrogenesis of mid-ocean ridge basalts. In McElhinney, M. W. (Ed.), The Earth; Its origin, structure and evolution, London (Academic Press), 265-299.

Green, D. H., and Ringwood, A. E., 1967. The genesis of basaltic magma. Contrib. Mineral. Petrol., 15:103-190.

Grove, T. L., 1981. Use of FePt alloys to eliminate the iron loss problem in 1 atmosphere gas mixing experiments: Theoretical and practical considerations. Contrib. Mineral. Petrol., 78:298-304.

Grove, T. L., and Bryan, W. B., 1983. Fractionation of pyroxenephyric MORB at low pressure: an experimental study. Contrib. Mineral. Petrol., 84:293-309.

Johannes, W., Bell, P. M., Mao, H. K., Boettcher, A. L., Chipman, D. W., Hays, J. F., Newton, R. S., and Seifert, F., 1971. An interlaboratory comparison of piston-cylinder pressure calibration using the albite breakdown reaction. Contrib. Mineral. Petrol., 32:24-38.

Lindsley, D. H., 1970. Melting relations of plagioclase at high pressures. New York State Museum and Science Service Memoir, 18:39-46.
Longhi, J., Walker, D., and Hays, J. F., 1976. Fe and $\mathrm{Mg}$ in plagioclase. Proc. Lunar Sci. Conf. 7th, 1281-1300.

Machado, N., Ludden, J. N., Brooks, C., and Thompson, G., 1983. Fine scale isotopic heterogeneity in the sub-Atlantic mantle. Nature, 295:226-229.

Presnall, D. C., and Hoover, J. D., 1984. Composition and depth of origin of primary mid-ocean ridge basalts. Contrib. Min. Pet., $87: 170-178$

Stolper, E., 1980. A phase diagram for mid-ocean ridge basalts: Preliminary results and implications for petrogenesis. Contrib. Mineral. Petrol., 74:13-27.

Tormey, D. R., Grove, T. L., and Bryan, W. B., 1987. Experimental petrology of normal MORB near the Kane Fracture Zone: $22^{\circ}-25^{\circ} \mathrm{N}$, mid-Atlantic ridge. Contrib. Mineral. Petrol., 96:121-139.

Date of initial receipt: 15 January 1988

Date of acceptance: 1 May 1989

Ms 106/109B-114 